\title{
FGF23 wt Allele
}

National Cancer Institute

\section{Source}

National Cancer Institute. FGF23 wt Allele. NCI Thesaurus. Code C104383.

Human FGF23 wild-type allele is located in the vicinity of 12 p13.3 and is approximately 12 $\mathrm{kb}$ in length. This allele, which encodes fibroblast growth factor 23 protein, plays a role in regulation of phosphate homeostasis. Mutations in this gene are associated with autosomal dominant hypophosphatemic rickets (ADHR) and familial tumoral calcinosis with hyperphosphatemia. It is overexpressed in oncogenic hypophosphatemic osteomalacia $(\mathrm{OHO})$. 